\title{
Representation of Graph Theory in Students' Communication Network at Female Students' Dormitory of State Islamic Institute of Palopo
}

\author{
Muhammad Hajarul Aswad A ${ }^{1}$, Wahyuni Husain² \\ ${ }^{1}$ Department of Mathematics Education IAIN Palopo \\ ${ }^{2}$ Department of Islamic Broadcasting Communication IAIN Palopo \\ Email: as wad82@yahoo.co.id,yuni h98@yahoo.com
}

\begin{abstract}
The application of Graph Theory Concept in Communication Network Analysis is interesting to observe. This research was carried out to learn how Communication Network structure was formed and who had necessary role in the network. It was explorative research and conducted at Female Students' Dormitory of State Islamic Institute of Palopo (Asrama Putri IAIN Palopo). The results were interpreted by using Microsoft NodeXL Version 1.0.1.113. It was found that the communication network structure of female students' who stayed at the Dormitory decentralized. It shows that each student had same opportunity to communicate one another directly or indirectly, which 4 to 9 path distance. It was also identified that from 110 people, Suarni was the student who had significant influence in the communication network.
\end{abstract}

Keywords: Communication Network Analysis, Microsoft NodeXL, Graph Theory.

\section{INTRODUCTION}

Graph theory is an applied science which is very suitable to apply in network analysis case in term of communication network. Furthermore, it is said that Communication Network Analysis is the application of Social Network Analysis, yet CNA focuses more on communication such as identifying communication structure in a system and how actors (person, organization, or institution) in the organization structure.

\section{THEORITICAL REVIEW}

Looking at the Communication Network Analysis, there are usually some basic terms of Graph Theory used. The terms are briefly explained as follow:

Table 1. The Basic Concept of Graph Theory in Communication Network Analysis

\begin{tabular}{|c|c|c|}
\hline Terms & Graph Theory Concept & The Concept of Communication Network Analysis \\
\hline Vertex & Point, dot, node & $\begin{array}{l}\text { Members of Network, actors, people, companies, and } \\
\text { others depending on network objects }\end{array}$ \\
\hline Edge & Side, line & Link, relations \\
\hline Degree & $\begin{array}{l}\text { the number of edges and vertex } \\
\text { side by side }\end{array}$ & $\begin{array}{l}\text { The number of links/relations occurred at an actor } \\
\text { with others }\end{array}$ \\
\hline $\begin{array}{l}\text { Isolated } \\
\text { Vertex }\end{array}$ & Vertex with degree 0 & Actors have no relation to others \\
\hline
\end{tabular}




\begin{tabular}{|l|l|l|}
\hline Hubs & $\begin{array}{l}\text { Vertex has much more degree } \\
\text { compared to other vertices }\end{array}$ & Actors have most links in a network \\
\hline
\end{tabular}

The relation of actors (female students) who stay at Female Students' Dormitory of State Islamic Institute of Palopo (Asrama Putri IAIN Palopo) was based on emotion among them. This interaction happened not to obtain anything with the exception of comfort and fulfillment of emotional need. Such kind of relation was then then called as sentimental relation, where the relation had no direction (undirected). Based on the interaction, form of graph/network would be undirected graph.

To observe the structure and character in the network, there several things need noticing: 1. Density: ratio of link number in a network and the number of links that might appear. The density demonstrates intensity of each actors' network in communicating. The network with high density is the network which has actors interacting one another. On the contrary, the network with low density is indicated with the less interaction among actors. Density in a network can be calculated with the pattern as follows:

$$
D=\frac{1}{N(N-1)}
$$

$\mathrm{D}=$ Density, $I=$ link number, and $N=$ network size or actor number in a network. The grade of density is about between 0 up to 1 , where approaching 1 means that density of a network is getting higher.

2. Centralization: an indication how focus a network is used by certain actors. Whether relation in a network spreads to many people or only centralize on several users. A network is called centralized when the link points to some certain actors, while a network connects to many users is decentralized. Centralization has no connection with density. A network with high density could have centralized and decentralized networks. The same condition happened to the network with a low density. The equation which is used to decide centrality of a network is as follows:

$$
C D=\frac{\sum\left(\operatorname{Max}\left(C_{D i}\right)-C_{D i}\right)}{N^{2}-3 N+2}
$$

$\mathrm{CD}$ is centralization, CDi level centrality scores from each actor Max CDi maximum score from $\mathrm{CDi}$, and $\mathrm{N}$ is the number of actors .

3. Distance and diameter: distance is average path required by all actors to communicate. Meanwhile, diameter is the farthest distance between two actors in a network.

4. Betweennes Centrality is the each of actor's scores that indicate how the actors relate in a network. An actor with the biggest Betweenness Centrality score illustrates the actors' existence, which then show others' existence in a network. If actor A is disconnected in a network, which then causes other actors separated from the network, actor A has high betweenness centrality score. The lowest score of betweenness centrality is 0 and the highest one is 1 .

Closeness Centrality is the measurement how important/close an actor to other actors in a network. The lower the Closeness Centrality score of an actor, the more important/closer the actor with others is.

\section{METHODOLOGY}

Network analysis in this research was Complete Network Analysis where all actors in the network had same attention to observe and analyze. If we look at the analysis, the research used system analysis level where the researcher did not pay attention on actors or certain groups, but more on network structure comprehensively. It was explorative research which would illustrate the students who were mostly chosen for communicating at Female Students' Dormitory of State Islamic Institute of Palopo (Asrama Putri IAIN Palopo). Furthermore, network structure was identified through network measurements covering network density, centrality, distance, and diameter, betweenness centrality, and closeness centrality. 
The research was conducted at Female Students' Dormitory of State Islamic Institute of Palopo (Asrama Putri IAIN Palopo) at jln. Agatis, Balandai, Palopo City, South Sulawesi. The dormitory was utilized by female students that had fulfilled requirement and provision assessed by boarding house committee at IAIN Palopo. The number of undergraduate students who stayed at the dormitory till 10 january 2016 was 110 . However, in the further observation process (4 10 January 2016) there were only 71 people to take their data sucessfully.

The method of collecting data was through questionnaire controlled by a surveyor. The questionnaire content consisted of two parts which were the first one was related to sosiogram data and the second one was connected to the closeness of relationship among female students who stayed at Female Students' Dormitory of IAIN Palopo. The restricted interview was also administered to several students related to the questions in the questionnaire. The collected data was then analyzed with method of communication network analysis by using Microsoft NodeXL Version 1.0.1.113.

\section{RESULTS AND DISCUSSION}

The data of observation results was firstly tabulated, which then became input in Microsoft NodeXL. the sosiogram output was as follows:

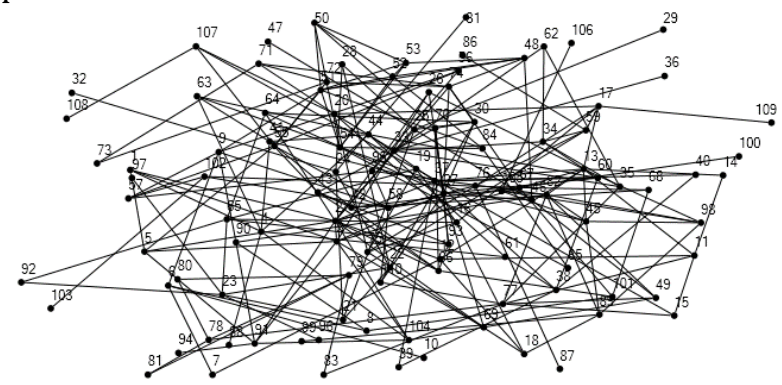

Figure 1. Communication Network Sosiogram at Female Students' Dormitory of IAIN Palopo

Basic information of the communication network of students at Female Students' Dormitory of IAIN Palopo on the Picture 1 could be showed with the following tables (Table 1 and 2).

Tabel 1. The summary of Graph Metrics NodeXL toward Communication Network at Female Students' Dormitory of IAIN Palopo.

\begin{tabular}{|c|c|}
\hline Metrics & Value \\
\hline Graph Type & Undirected \\
\hline Vertices & 110 \\
\hline Unique Edges (link) & 236 \\
\hline Edges With Duplicates & 0 \\
\hline Total Edges & 236 \\
\hline Self-Loops & 0 \\
\hline Single-Vertex Connected Components & 1 \\
\hline Maximum Vertices in a Connected & 0 \\
\hline Component & 110 \\
\hline Maximum Edges in a Connected & 236 \\
\hline Component & 9 \\
\hline Maximum Geodesic Distance & 3,89 \\
\hline Average Geodesic Distance &
\end{tabular}




\begin{tabular}{|c|c|}
\hline Graph Density & 0,04 \\
\hline NodeXL Version & 1.0 .1 .113 \\
\hline
\end{tabular}

Looking at Table1, it can be seen that graph/network formed a(Pict. 1) was undirected graph. The number of vertex/actor/ $N=110$, and edge number / link / $I=236$. The formed graph was connecting graph with the smallest degree 1 and the biggest one 15 .

Based on the equation (1), the density of network was 0.019. It means that interaction among the students at Female Students' Dormitory of IAIN Palopo was still in the low level. Many students were not connected directly or did not know each other. The circumstances happened because the students who stay at the dormitory were heterogeneous in ethnic group, department, and semester. The relation also demonstrates that decentralization did not just focus on several people. It is seen that centralization proportion only accounted for $10.007 \%$.

The large amount of network diameter was 9. It illustrates that the communication network formed at Female Students' Dormitory of IAIN Palopo was relatively large. The distance required by each students at the dormitory in interacting was average $3,89 \approx 4$. The number describes that the students had to get in touch with 3 people at first before interacting or communicating with the intended student.

According to the data at Table 2, actor who had the highest betweenness centrality score was actor number 2, Suarni. It describes that Suarni was the actor that had the significant influence to the students at Female Students' Dormitory of IAIN Palopo. Moreover, Suarni also had the lowest closeness centrality score accounting for 2.633. It shows that Suarni played important role Female Students' Dormitory of IAIN Palopo. It is asserted by sosiogram on picture 2 as follows:
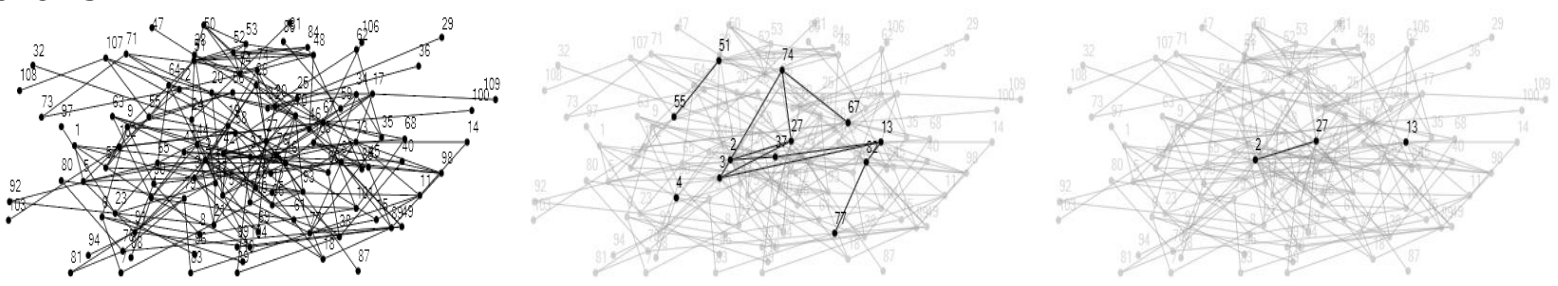

Picture 2. The forms of Communication Network Based on the Number of Minimum Degree 1, 7, 10.

\section{CONCLUSION}

Based on research findings and discussions, it can be concluded that communication network structure of students at Female Students' Dormitory of IAIN Palopo decentralized. It shows that the communication tended to spread evenly, it did not focus only for several people. Every female student could still communicate in direct and indirect ways with communication distance average 4 to 9 paths. Suarni, actor number 2, was the student who had adequately significant influence in the communication network.

\section{REFERENCE}

[1] M. Tsvetovat and A. Kouznetsov, Social Network Analysis for Startups: Finding connections on the social web, " O'Reilly Media, Inc.", 2011.

[2] P. Mathis, "Graphs and Networks: Multilevel Modeling," 2007. 
[3] D. Hansen, B. Shneiderman and M. Smith, "Analyzing social media networks: Learning by doing with NodeXL," Computing, vol. 28, no. 4, pp. 1-47, 2009.

[4] K. Faust, "Centrality in affiliation networks," Social networks, vol. 19, no. 2, pp. 157-191, 1997.

[5] Eriyanto, Analisis Jaringan Komunikasi, Prenadamedia Group, 2014. 